\title{
Class Structure and Social Mobility in the Chinese Community in Singapore and Malaya I8OO-I9I I
}

\author{
YEN CHING-HWANG
}

\section{The University of Adelaide}

THE social history of the Chinese community in Singapore and Malaya in the nineteenth and early twentieth centuries cannot be fully understood if aspects of class structure and social mobility are not examined. Of course, the social relations of the Chinese were principally determined by kinship and dialect ties, but they were also affected by class affiliations. Class status, like kinship and dialect relations distanted Chinese immigrants from one another. This paper seeks to examine the nature and structure of Chinese classes, class relations and the channels of social mobility in the Chinese community in Singapore and Malaya during the period between 1800 and 1911 . The findings of this paper may be applicable to other overseas Chinese communities in the same period outside this region.

\section{Class Structure}

Before discussing the class structure of Chinese society in Singapore and Malaya during this period, three points need to be borne in mind: firstly, the overseas Chinese society was a predominantly immigrant community; secondly, it was a subordinate community in terms of power and authority; and thirdly, it was an urban community. Its nature thus determined its class structure. As an immigrant community, it was characterized by an unstable population. Many immigrants treated their time overseas as sojournment rather than settlement; those who succeeded in making enough money returned to China, while many others continued to travel overseas to try their luck. This fluctuation in population affected the profile of the class structure, and membership of the classes, in particular the workers, changed frequently. Since the society was a subordinate one, it did not have a fully-grown class system, 0026-749X/87/0202-0907 S05.00 C) 1987 Cambridge Lniversity Press 
comprising a ruling class and a sizable peasant class as China. As it was predominantly urban, it produced largely merchants and workers rather than landlords and peasants.

Professor Wang Gungwu had rightly pointed out more than a decade ago that the overseas Chinese society was vastly different from the traditional Chinese society in terms of class structure. It was divided into two major groups: 'Shang' (Merchant) and 'Kung' (Worker). ${ }^{1} \mathrm{He}$ also suggested that the 'Shang' class should include merchants and shopkeepers, and the 'Kung', artisans, and perhaps clerks, teachers and squatters. ${ }^{2}$ This classification is generally sound, but it would seem that a modified three-class paradigm is even more satisfactory, that is 'Shang', 'Shih' (educated elite) and 'Kung'. Under this classification, the merchants still occupied the top social stratum underlying a thin layer of educated elite above the workers. The 'Shang' class consisted of traders, shopkeepers, exporters and importers, plantation owners, property owners, financiers and tin-mining proprietors. The 'Shih' class consisted of clerks of foreign and Chinese firms, junior government officers, interpreters, school teachers and professionals. The 'Kung' class consisted of artisans, shop assistants, plantation workers, mining workers and rickisha pullers.

More generally, the 'Shang' class could be sub-divided into two: capitalists and general merchants. The former consisted of exporters and importers, big plantation owners, tin-mining proprietors, big contractors, property owners and financiers; while the latter consisted of shopkeepers, general traders and small plantation owners. Many of the capitalists under our classification had little to do with buying and selling goods which is the conventional definition of a 'merchant'. They had possessed the essential characteristics of 'modern capitalists' such as entrepreneural spirit, reinvestment of capital and the use of modern financial institutions. The reason for including them in the 'Shang' class is partly because they did not identify themselves as 'capitalists' (Tzupen chia), but rather using the term 'Shang'; a good example is that many mining proprietors called themselves ' $K$ 'uang-shang' (mining merchants). ${ }^{3}$

${ }^{1}$ See Wang Gungwu, 'Traditional Leadership in a New Nation: The Chinese in Malaya and Singapore', in G. Wijeyawardene (ed.), Leadership and Authority: A Symposium (Singapore, 1968), p. 2 10; see also Wang Gungwu, Community and Nation: Essays on Southeast Asia and The Chinese (Singapore, 1981), p. 162.

2 Ibid.

${ }^{3}$ This term is still popularly used in Singapore and Malaysia. The association of mining proprietors is called ' $\mathrm{K}$ 'uang-shang kung-hui', and the term ' $\mathrm{K}$ 'uang-shang' is frequently used by local Chinese newspapers to refer to those mining proprietors. 
The 'shih' class is also divided into two groups: The upper and lower. The former consisted of professionals, junior government officials, interpreters and clerks of foreign firms; while the latter consisted of Chinese school teachers and clerks of Chinese firms.

The 'Kung' could also be sub-divided into two groups: artisans and general workers. The former consisted of carpenters, blacksmiths, goldsmiths, bricklayers, mechanics, cooks and tailors; while the latter consisted of shop assistants, plantation workers, mining workers and rickisha pullers. The dividing line between the artisans and general workers was the possession of a skill. The apprentices who aspired to become artisans fall between these two categories: before gaining the skill they should be treated as general workers, but they should be considered as artisans after they had acquired the skill and worked with that skill for a livelihood. Thus at the apex of the class hierarchy in the overseas Chinese society in this period was a small group of 'capitalists', and in the descending order were a large group of general merchants, a small middle class, a small group of artisans and a large group of general workers.

The main characteristic of the overseas Chinese class system is its fluidity. There was no legal barrier to social mobility, nor did it have the competitive examination system that people had to go through before higher status could be acquired. Wealth was the main determinant of social mobility; those who possessed it moved up to the apex of the class hierarchy, and those who lost it descended even down to the bottom. The expanding economy of Singapore and Malaya during this period provided many opportunities for Chinese to acquire wealth and to change their social status, and there was no quota restricting the number of people moving up the social ladder, which explains why movements between classes and between sub-classes were so frequent. In particular, movement from the upper 'Kung' class to the lower 'Shang' class was most frequent, because it was relatively easy for an artisan to change his status to become a shopkeeper. This fluidity had thus affected the shape of the classes in the overseas Chinese community.

The impact of Confucianism on the overseas Chinese class system was not so much on the formal class structure, ${ }^{4}$ as on the attitude of the overseas Chinese towards social groupings which led indirectly to the formation of classes. The Confucian hierarchical order expressed in

\footnotetext{
${ }^{4}$ For a discussion of the impact of Confucianism on traditional Chinese class structure, see Tung-tsu Chu, 'Chinese Class Structure and Its Ideology', in J. K. Fairbank (ed.), Chinese Thought and Institutions (Chicago, 1967), pp. 235-50.
} 
class, clan and family structures in China left an indelible impression on the minds of the immigrants before they left China. When they were overseas and congregated into a community, they naturally saw the new society structured hierarchically. They measured and graded other people according to the possession of wealth in a hierarchical order, and paid respect to those who possessed higher social status. In the process of grading other people, one could not help knowing his own status in that class hierarchy. This strong status consciousness provided an incentive for the overseas Chinese to acquire wealth and symbols of status. ${ }^{5}$

Class distinction in Chinese society in Singapore and Malaya during this period was not as conspicuous as that in China where the distinction was clearly reflected in the styles of houses, clothes, hats and carriages, ${ }^{6}$ but most overseas Chinese could be identified from their appearance as to which class they belonged. The desire to make wealth and status visible led many members of the 'Shang' and 'Shih' classes to dress differently from workers. They wore Chinese jackets and robes made of good and expensive material, probably of imported silk from Soochow and Hangchow. ${ }^{7}$ Good, expensive clothes kept them at a social distance from those who could not afford such clothes, and enhanced their selfrespect. In Chinese society in Singapore and Malaya where wealth could not automatically be translated into power and prestige, the outward appearance thus became a conspicuous way of expressing one's possessions. Song Ong Siang's story that a group of wealthy Singapore Chinese imposed the wearing of stockings among themselves is a clear

${ }^{5}$ Sing Po editorial commented that more and more Chinese merchants were interested in acquiring Ch'ing official titles because of their increasing consciousness of status and prestige. See $\operatorname{Sing} P o, 9 / 8 / 1892$, pp. I and 8 . For a discussion of the motives of acquiring Ch'ing titles by the Chinese in Singapore and Malaya during this period, see Yen Chinghwang 'Ch'ing's Sale of Honours and the Chinese Leadership in Singapore and Malaya 1877-1912', in Journal of Southeast Asian Studies, vol. I, no. 2 (Singapore, 1970), pp. 2032.

${ }^{6}$ See Ping-ti Ho, The Ladder of Success in Imperial China (New York, 1964), pp. $18 \mathrm{ff}$.

7 The wearing of Chinese jackets and robes can be seen from photographs of some wealthy Chinese in Singapore, in particular the photograph of Hoo Ah Kay, Tan Beng Swee, Ong Sam Leong, Wee Ah Hood, and Lee Cheng Yan, see Song Ong Siang, One Hundred Years' History of the Chinese in Singapore (London 1923; Singapore, 1967, reprint), pp. 52-III; I guess that most of the jackets and robes of these wealthy Chinese were made of good quality silk, partly because a large quantity of Soochow and Hangchow silk (the best produced in China) was imported and sold in Singapore. Chop Mei Jui Ho, for instance, was famous for its dealing in Soochow and Hangchow silk. See Huang Shan-ju, 'Wu-Shih chiu nien te hui-ku' (Reminiscence of My Past Fifty-Nine Years), in Huang Chai-ning (ed.), Hsin-chia-po Ning-yang hui-kuan i-pai san-shih chou-nien chi-nien t'e$k^{\prime}$ an (Souvenir Magazine of 1 3oth Anniversary Celebration of the Ning Yeung Association of Singapore) (Singapore, 1952), 'lun-chu' column, pp. 9-12. 
indication of such a consciousness that wealthy merchants belonged to a different social class. ${ }^{8}$

By contrast, the members of the 'Kung' class dressed poorly. Partly because of their direct involvement in physical labour, they usually wore short jackets and short trousers made of coarse Nankeen and of unbleached material; they also wore bamboo hats to protect them from the sun, and they went bare-footed. ${ }^{9}$

These different appearances not only reflected differences in the nature of their work, but also differences in income. Indeed, it was the income differential that mainly determined their class status. Generally speaking, income differences between members of the upper 'Kung' class, the 'Shih' class, and the lower 'Shang' class were not very great; a self-employed artisan or a skilled worker earned as much as a shopkeeper, a clerk in foreign firm or a junior government officer. ${ }^{10}$ But the income of a wealthy capitalist was many times the earnings of an ordinary worker. In the mid-nineteenth century, an average agricultural worker was paid $\mathrm{S} \$ 3$ to $\mathrm{S} \$ 4$ a month, ${ }^{11}$ and his yearly income did not exceed $\$ 50$. Towards the end of the nineteenth and the beginning of the twentieth centuries, the income of the average worker increased to $\mathrm{S} \$ 7$ to $\mathrm{S} \$ 9$ per month, ${ }^{12}$ and his annual income was probably about $\$ 1$ oo. On the contrary, the yearly income of a capitalist was probably tens of thousands of dollars. Gan Ngoh Bee, a wealthy capitalist from

${ }^{8}$ In February $\mathrm{I} 869$, some wealthy Chinese merchants issued a circular requesting their friends to distinguish themselves from the members of the lower classes by wearing stockings. See Song Ong Siang, Chinese in Singapore, p. 153.

${ }^{9}$ See Siah U Chin (Seah Eu Chin), 'General Sketch of the Numbers, Tribes, and Avocations of the Chinese in Singapore', in Journal of the Indian Archipelago and Eastern Asia, vol. 2 (Singapore, 1848 ), p. 288.

${ }^{10}$ In 1907 , a skilled worker (fitter, moulder or brass worker) employed by the Messrs Riley Hargreave \& Company Ltd earned at least \$1 .4 per day. He worked 6 days a week or more, so his income must have been at least $\$ 36$ per month. A junior officer, such as clerk or draughtsman, earned between $\$ 40$ and $\$ 50$ a month in 1890 . See 'Evidence given by C. E. F. Saunderson, Acting Managing Director of Messrs. Riley Hargreaves \& Co. Ltd., on Ioth August 1907', in Straits Setllements and Federated Malay States Opium Commission 1908, Proceedings, vol. 2, p. 34; The Perak Government Gazette, I89o, vol. 3, no. 14, p. 284; The Perak Government Gazelle, I 89 I, vol. 4, no. 4, p. 64 .

${ }^{1}$ Siah U Chin, 'General Sketch' (see n.9), pp. 288-9; in 1847, Dr R. Little interviewed a group of opium smokers in prison in Singapore and found that most of them (29 out of 35 ) were coolies who spent most of their income on opium. The average monthly income was about $\mathrm{S} \$ 4$. See $\mathrm{R}$. Little, 'On the Habitual Use of Opium in Singapore', in Journal of the Indian Archipelago and Eastern Asia, vol. 2 (1848), pp. $4^{1-2}$.

${ }_{12}$ At the turn of the present century, tin-mining workers in Malay earned between $S \$ 5$ and $S \$ 8$ per month. In $191 \mathrm{I}$, the agricultural workers were paid from $S \$ 5$ to $S \$ 9$ in Singapore and from $S \$ 6$ to $S \$ 12$ in Penang. See Straits Setllements Blue Books, 19 I I , p. W 3 ; R. N. Jackson, Immigrant Labour and the Development of Malaya, 1786-1920 (Kuala Lumpur, 1961), p. 89 . 
Penang, had a yearly income of $\$ 5^{\circ}$,ooo from the Penang Opium and Spirit Farms in the period between I $90 \mathrm{I}$ and $\mathrm{I} 903 .{ }^{13}$ From the amount of money that wealthy capitalists donated to charitable organizations, we can also get some idea of their income and wealth. In 1888 a wealthy Chinese capitalist, Yeh Po-hsuing (Chih-ying), donated 5,00o taels to flood relief funds in Kwangtung. ${ }^{14}$ In I 889 , a group of wealthy Chinese capitalists donated a large sum of money to the relief funds for the drought in Central China. They were led by Tan Kim Cheng who donated 4,00o taels, followed by Wu Hsiu-shui 3,00o taels, Wu Hsin-k'o 2,ooo taels, Tan Jiak Kim 600 taels, Hoo Ah Kay (or Chop Hoo Nan Sheng), Seah Liang Seah and Huang Chin-yen 400 taels each. $^{15}$ Another famous capitalist in Singapore, Cheang Hong Lim (sometimes romanized as Chang Huang-lin), together with his three sons donated a sum of $\$ \$ 7970$ to the relief funds for the flood in Shantung province in I 889. ${ }^{16}$ Cheang had gained a reputation as a great philanthropist, and was said to have donated more than $\$ \$ 100$, 000 to the poor over the years. ${ }^{17}$ Towards the end of his life, he fixed a sum of $\mathrm{S} \$ 3000$ as his contribution towards any deserving charity which appealed to him. ${ }^{18}$ Although some of these donations were not really for charitable purposes, but for paying for Ch'ing brevet titles, ${ }^{19}$ they nevertheless show the donor's wealth.

Class difference could also be measured in terms of the ownership of property. All general workers owned nothing as far as property was concerned. Their accommodation was usually provided by their employers. Shop assistants lived in the shops helping to look after the security of the shops; ${ }^{20}$ agricultural workers lived in wooden houses with attap roofing in the plantations; ${ }^{21}$ mining workers also lived in 'Kongsi house' which was made of timber or split bamboo, and was constructed

${ }^{13} \mathrm{Gan}$ Ghoh Bee was the head of a syndicate which controlled the Penang Opium and Spirit Farms between I 901 and 1903 . The net profit of the Farm was $\$ 700$,000. Gan held one-fourth share of the syndicate which amounted to $\$$ i 50,000 for those three years. See 'Correspondence regarding the Reduction in the Rent of the Penang Opium and Spirit Farms', in Straits Settlements Legislative Council Proceedings 1905, appendix no. ro.

${ }^{14}$ See Lat Pau (The Straits Daily), 1/9/1888, p. $2 . \quad{ }_{15}$ Lat Pau, 14/2/1889, p. 2.

16 Under Hong Lim's name, a sum of $\$ \$ 4000$ was donated, his son Jim Hean donated S\$1 725 , another son Jim Kheng $\$ 795$, and another son Jim Chwan S\$1450. See The Straits Times, 3/1/189o, p. 2; Lat Pau 5/2/189o, pp. 5-6.

${ }^{17}$ See Song Ong Siang, Chinese in Singapore, p. $169 . \quad 18$ Ibid., p. 184.

${ }^{19}$ Obviously that donations for various relief funds in China were the payment for the purchase of Ch'ing honours. For details, see Yen Ching-hwang, 'Ch'ing Sale of Honours and the Chinese Leadership in Singapore and Malaya 1877-1912', in Journal of Southeast Asian Studies, vol. 1, no. 2 (Sept. 1970), pp. 20-32.

${ }^{20}$ This practice still can be seen in shops in Singapore and Malaysia.

21 See Siah U Chin, 'General Sketch' (see n. 9), p. 288. 
for temporary purpose in the compound of the mines. ${ }^{22}$ While some artisans and shopkeepers owned shops, many probably rented their places for business which they sought to eventually buy. Many urban shops were becoming more valuable as the population increased and business expanded, which of course put the shops in good locations beyond the reach of ordinary shopkeepers, but this also provided excellent opportunities for capitalists to invest in property and to reap handsome profits. It is not an exaggeration to claim that many capitalists were involved in real estate speculation because of its quick appreciation in value. In 1875,82 owners of house property in Singapore petitioned the government against the enforcement of the Gaming House Ordinance of $1870 ; 64$ of them were Chinese merchants. Prominent signatories were Cheang Hong Lim, Tan Seng Poh, Lee Cheng Yan, Seah Eu Chin and Low Kim Pong. ${ }^{23}$ Obviously the majority of the property owners in Singapore during this time were Chinese capitalists who had houses (shops) to let and feared to be implicated in gambling in the properties they owned. Seah Eu Chin, one of the wealthiest Chinese capitalists in the Straits Settlements, owned many properties, plantation estates and an export-import business. ${ }^{24}$ At the time of his death in 1883 , his estate was estimated to be worth $\mathrm{S} \$ \mathrm{I}, 359,000 .{ }^{25}$ In $\mathrm{I} 885$ at the time of his death, famous Kapitan Yap Ah Loy owned more than i 50 houses in Kuala Lumpur, in addition to extensive tin mines and plantations in various parts of Selangor. ${ }^{26}$

The overseas Chinese classes in Singapore and Malaya not only distinguished their status in income and possession of property, but also expressed it in different life styles. Most of the wealthy capitalists were married with a family, ${ }^{27}$ and sometimes had several wives or concubines. ${ }^{28}$ They lived in well-constructed mansions and villas, ${ }^{29}$ dressed in

${ }^{22}$ See Selangor Journal, vol. 4 (Kuala Lumpur, 1895), pp. 27-9.

${ }^{23}$ See the 'Petition of House-Owners in Singapore to the Governor and the Members of the Legislative Council of the Straits Settlements dated 29th October, 1875 ', in Straits Settlements Legislative Council Proceedings 1876, appendix no. 9.

${ }^{24}$ See Song Ong Siang, Chinese in Singapore, p. 20.

${ }^{25}$ See a court case involved in the dispute over inheritance of the estate of Seah Eu Chin (Siah U Chin) between Seah Liang Seah and Seah Eng Kiat, in Straits Settlements Law Reports, vol. 4 (1897), p. 28.

${ }^{26}$ See 'Annual Report on the State of Selangor for the Year I 885 ', in Straits Settlements Legislative Council Proceedings 1886, appendix no. 22, p. 284.

${ }^{27}$ See Siah U Chin, 'General Sketch' (see n. 9), p. 284

${ }^{28}$ For instance, a wealthy Chinese capitalist, Cheng Keng Kuei, once a Chinese Kapitan of Perak, had several wives and concubines; another wealthy Chinese in Penang, Hseuh Tseng-i also had at least five wives and concubines. See K'uang Kuohsiang, Ping-ch'eng san-chi (Anecdotes of Penang) (Hong Kong, 1958), pp. I I 3, I 20.

29 A number of mansions were built in Singapore in the second half of the $19^{\text {th }}$ 
expensive silk, and travelled in beautifully-decorated coaches; and their women-folk wore gold jewellery. ${ }^{30}$ They organized feasts and threw expensive parties. They celebrated lavish birthdays ${ }^{31}$ and acquisitions of honours with banquets, fireworks and theatrical performances. ${ }^{32}$ They not only enjoyed their wealth and expressed it, but also enjoyed their leisure in a way that many ordinary Chinese could not afford to do. Some of them gathered regularly in each other's villas, drinking tea or wine, reciting poetry and enjoying each other's company. In Singapore, for instance, a group of about $3^{0}$ wealthy Chinese led by Cheang Hong Lim met on every Monday to enjoy food, drink and literary programmes. ${ }^{33}$

The members of the lower stratum of the 'Shang' class, the shopkeepers, lived a completely different life from the capitalists. They spent most of their time in the shops. As the eight-hour work system was not yet known in the overseas Chinese community, they worked long

century by these wealthy capitalists. One of the mansions which was built by a wellknown Teochew, Ch'en Hsu-nien, still exists in Singapore. See Chang Ch'ing-chiang, 'Ch'en Hsu-nien yu tzu-cheng ti' (Ch'en Hsu-nien and his Mansion), in Lin Hsiaosheng and others, Shih-le ku-chi (The Historical Relics of Singapore) (Singapore, 1975), pp. 225-3o. Apart from mansions, the rich also built villas and gardens for enjoyment of their life. Cheang Hong Lim had a famous 'Ming Yun villa', Wu Chin-ch'ing, also known as Wu I-ting had a villa named 'Teh Yuen Garden'. But the most famous garden was built by Hoo Ah Kay named 'Nam Sang Garden' which impressed many European and Chinese visiting dignitaries. See Lat Pau, 5/6/1 888, p. I; Sing Po, 3/5/1892, p. I; Kuo Sung-t'ao, Shih-hsi chi-ch'eng (The Record of an Envoy's Journey to the West); see also J. D. Frodsham's English translation, in J. D. Frodsham (trans.), The First Chinese Embassy to the West: The Journals of Kuo Sung-l'ao, Liu Hsi-hung and Chang Te-yi (Oxford, I974), pp. 1 $3^{-1} 4$.

30 See Lat Pau, 10/12/189o, p. i; see also Yen Ching-hwang, 'Ch'ing Sale of Honours', p. 28 .

${ }^{31}$. For instance, a wealthy capitalist in Singapore, Choa Chong Long, celebrated his forty-fourth birthday by giving a grandiose dinner to all influential residents in the island, including many Europeans. European dishes and Chinese luxuries were served. See The Singapore Chronicle, 9/6/1831; C. B. Buckley, An Anecdotal History of Old Times in Singapore $1819-1867$ (Kuala Lumpur, 1965, reprint), p. 21 5; Song Ong Siang, Chinese in Singapore, pp. 29-30.

${ }^{32}$ For instance, a wealthy capitalist in Singapore, Wu Hsin-k'o (or known as Wu Chin-ch'ing, or Wu I-ting, and in Song Ong Siang's work romanized as Goh Sin Kho), celebrated the occasion of receiving a tablet deed from the Ch'ing court in June I 888. A big party was thrown in his villa, Teh Yuan Garden, with fireworks. Among those invited were other wealthy capitalists and the Ch'ing Consul, Tso Ping-lung. Wu was the proprietor of the firm Goh Guan Loo and Company owning several saw-mills at Kallang and owner of steamships. Another wealthy capitalist, Khoo Seok Wan, in October I go I celebrated his acquisition of the Chu-shih title and the Fourth Rank, and more than five hundred guests were invited. See 'Teh-yuan yuan t'i-ch'in chi' (The Gathering in the Teh Yuan Garden), in Lat Pau, 5/6/1 888, p. 1; Song Ong Siang, Chinese in Singapore, P. 318; Thien Nan Shin Pao, 26/10/1901, p. 9, 29/10/1901, p. 2.

${ }^{33}$ See Sing Po, 3/5/1892, p. 1 . 
hours. Many of them had families, and they lived above their shops, their wives and children helping to look after the shops. ${ }^{34}$ When a shopkeeper tried to establish himself in the business, he had to work extremely hard, and so did his wife and children. Because of long working hours, most shopkeepers were physically tired, with no means to enjoy a life of leisure or entertainment. But they still found time to help nursing babies and amuse their children, and they looked happy and contented. ${ }^{35}$ A shopkeeper spent most of his life in his shop. Its activities were the centre of his existence.

The life style of the artisan who owned a small business was similar to that of the shopkeepers, and his workshop became the hub of his world, which, though confined, was materially well-off. Artisans could not live a luxurious life like the capitalists, but they had enough food to eat and enough clothes, and they had reasonable accommodation.

The life of ordinary workers (coolies) ${ }^{36}$ was the worst among the overseas Chinese. Most of them were young male sinkheh (new arrivals) ${ }^{37}$ who were single; those among them who were married in China usually left their wives behind. ${ }^{38}$ They worked long hours to eke out a living and to save some money in order to return to China with wealth. Long hours of hard work generated frustration, and in view of the lack of healthy entertainments, they were induced to indulge in gambling and opium smoking. ${ }^{39}$ Because of the lack of female companionship, they sought temporary relief in brothels. ${ }^{40}$ The

${ }^{34}$ This practice is still common among shopkeepers in small towns in Malaysia.

${ }^{35}$ See J. D. Vaughan, The Manners and Customs of the Chinese of the Straits Settlements (Taipei, 197 I, reprint), p. 26.

${ }^{36}$ Coolie is the transliteration of a Chinese term 'K' $u$-li' which means labourers. The term coolie became so popular in the West because of the massive number of Chinese labourers shipped to the new world. For a discussion of this term, see R. L. Irick, 'Ch'ing Policy Toward The Coolie Trade, $1847-1878$ ' (an unpublished Ph.D. thesis of Harvard University, 1971), vol. 1, p. 3 .

${ }^{37}$ The term 'sinkheh' seems to be the romanization according to a Southern Fukienese dialect of 'Hsin-k'e' which literally means new guests.

${ }^{38}$ See R. N. Jackson, Immigrant Labour and The Development of Malaya, p. $5 \mathrm{I}$.

${ }^{39}$ Both official and private records have indicated that gambling and opium smoking were rife in the overseas Chinese community during this period. See J. D. Vaughan, 'Notes on Chinese of Pinang', in Journal of The Indian Archipelago and Eastern Asia, vol. 8 ( 1854 ), pp. 25-7; J. D. Vaughan, The Manners and Customs of the Chinese of the Straits Settlements, pp. 58-62; Lat Pau, $27 / 1$ 1/1887, p. I; C.O. 273/257, p. 625. Annual Departmental Reports of the Straits Setllements, 1904, pp. 108-9; Annual Departmental Reports of the Straits Settlements, i 908 , pp. 87-98.

40 The need of this large number of single male workers was reflected in the number of brothels and prostitutes. In 1905 , there were 383 brothels in Singapore, 144 in Penang and 21 in Malacca; and there were 2710 prostitutes in Singapore, 1201 in Penang and 158 in Malacca. This gives a total number of 548 brothels in these three cities, and the 
indulgences in these vices reduced their ability to save money, and resulted in the shattering of their dreams of accumulating wealth and returning to their home villages with honour. According to Seah Eu Chin, only ten per cent of these sinkhehs were able to fulfil their dreams of returning to China with some savings in the mid-nineteenth century. ${ }^{41}$ Presumably the remaining ninety per cent had to struggle in poverty for the rest of their lives. The lack of unemployment benefits and old age pensions made them destitute once they were out of a job or grew old. Some lucky ones could depend on the charity of the dialect and clan organizations to which they belonged, ${ }^{42}$ and some could depend on other charitable organizations to help relieve the miseries of old age. ${ }^{43}$ Many were reduced to becoming beggars, ${ }^{44}$ and some who were emaciated by poverty, diseases and opium smoking, took their own lives in despair. ${ }^{45}$

Class distinction was also reflected in prestige, status and power. The members of the 'Shang' class were generally given higher status than members of 'Kung' class in Chinese society and by the British Colonial government. As wealth was an important prerequisite for Chinese community leadership, the wealthy capitalists were given leadership status, and those among them who were able, charitable and with total number of prostitutes was 4069 . Apart from these registered brothels and prostitutes, there were also many illegal brothels and prostitutes. See Annual Departmental Reports of the Straits Settlements, 1905, p. 631; Lat Pau, 24/12/1887, p. 2, 13/12/1888, p. I.

${ }^{41}$ See Siah U Chin, 'General Sketch', p. 285.

${ }^{42}$ See Yen Ching-hwang, 'Early Chinese Clan Organizations in Singapore and Malaya 1819-1911', in Journal of Southeast Asian Studies, vol. 12, no. I (March 198r), p. 81; J. D. Vaughan, 'Notes on Chinese of Pinang', p. 15; 'Hsueh-lan-ngo Char-yang hui-ch'un kuan shih' (A History of the Char Yang Recuperation Centre of Selangor', in Hsueh-lan-ngo Char-yang hui-kuan yu Char-yang hui-ch'un kuan pai-nien ta-ch'ing t'-k'an (Souvenir Magazine of Centenary Celebration of the Char Yang Association and the Char Yang Recuperation Centre of Selangor) (Kuala Lumpur, 1977), p. 8.

${ }^{43}$ For instance, a charitable organization named Chung-hua chi k'un-chi hui (The Chinese Charitable Association of Malacca) was founded by a British Missionary, William Milne, in $181 \mathrm{~g}$. Most of the recipients were crippled, old men and women. See William Milne (ed.), Ch'a-shih shu mei-yueh t'ung-chi chuan (The Examiner), vol. 7, ist year of Tao-kuang reign $(1821)$, pp. 5 a-5 b.

${ }^{44}$ In September 1849, there was a report in The Singapore Free Press about a serious problem created by beggars in Singapore streets. They become visible in Market, Malacca and Hill Streets. They became more active on Sundays in Brass Bassa Road, Queen, Victoria, Church, Bencoolen and Middle Streets after divine service. Presumably they begged from Europeans and created a great nuisance for the general public. See The Singapore Free Press, 28/9/1849; for others reports on beggars, see also Lat Pau, 23/ I/1 igo8, p. I.

${ }^{45}$ For instance, a coolie in Jelabu, Negri Sembilan, named Lim Nyun died in Jelabu hospital as the result of cutting his own throat. He was an old man emaciated by disease and opium smoking. See 'Negri Sembilan Secretariat Files (British Resident's Office)', I 902 , no. $44^{13}$. 
ambition would become leaders of the whole community. ${ }^{46}$ In the choice of leadership for the dialect and clan organizations, the wealthy were readily accepted as leaders because they commanded high status and prestige in society and were able to make substantial donations when required. ${ }^{47}$ To the British Colonial government, merchants as a class were desirable and useful, since they could directly contribute to the growth and prosperity of the colonies. ${ }^{48}$ Owing to this image, the merchants were given special status in relation to the government. Wealthy capitalists were selected to liaise with the government, to sit on semi-governmental committees such as Po Leong Kuk (Pao Liang Chi, an organization protecting Chinese females); ${ }^{49}$ they were conferred British honours, ${ }^{50}$ and were appointed to serve on the Legislative Council. ${ }^{51}$ An important body liaising between the government and the Chinese community was the Chinese Advisory Board which was set up in $1889 .{ }^{52}$ Reputable Chinese capitalists were selected from various dialect groups, ${ }^{53}$ and their duty was to consult on subjects affecting Chinese interests and to forward their decisions to the Governor. ${ }^{54}$ They

${ }^{46}$ See Yong Ching Fatt, 'Chinese Leadership in Nineteenth Century Singapore', in Hsin-she hsueh-pao (Journal of the Island Society) (Singapore, I 967), vol. I. pp. 6-1o.

${ }^{47}$ See Yen Ching-hwang, 'Early Chinese Clan Organizations in Singapore and Malaya', pp. 73-5.

${ }^{48}$ For instance, Raffles placed greater value on merchants than ordinary Chinese, and prepared to give merchants special treatment in the allocation of areas for their residence. See 'Notices of Singapore', in Journal of Indian Archipelago and Eastern Asia, vol. 8 (1854), p. 102 .

${ }^{49}$ For instance, on the Po Leong Kuk Committee in Singapore for the year I 898, wellknown capitalists such as Tan Jiak Kim, Lee Cheng Yan, Gan Eng Seng and Ngo Siu Tin (Goh Siew Tin), Wee Kim Yam and Seah Song Seah were among those who were selected to represent different dialect groups. See 'Annual Report on the Chinese Protectorate for the year I 898', in Straits Settlements Annual Departmental Report 1898 , p. 1 I 5 .

50 For example, Hoo Ah Kay and Tan Jiak Kim were conferred both British honours of C.M.G. and M.L.C., Seah Liang Seah, M.L.C., Lee Choon Guan, M.L.C., Eu Tong Seng, O.B.E., in Song Ong Siang, Chinese in Singapore, pp. 55, 112, 194, $213,33^{2}$.

${ }^{51}$ For instance, Hoo Ah Kay was made a member of Executive Council in 1869 , later an extraordinary member of the Executive Council; Seah Liang Seah was appointed a member of the Legislative Council in $\mathrm{I}_{83}$; Tan Jiak Kim was appointed a member of the Council in 1889 . Ibid., pp. 55, 194, 2 1 3.

${ }^{52}$ See 'Annual Report on the Chinese Protectorate, Singapore, for the Year 1889 ', in Straits Settlements Annual Departmental Reports 1889, p. I88.

${ }^{53}$ For instance, in the 1899 Chinese Advisory Board of Singapore, well-known capitalists such as Tan Jiak Kim, Lee Cheng Yan, Tan Cheng Tuan, Go Sin Kho represented Hokkien group, while Seah Liang Seah, Wee Kim Yam, Chua Tzu Yong, represented Teochew group. See 'Report on the Chinese Protectorate', in Straits Settlements Annual Departmental Reports I899, p. 302.

${ }^{54}$ See 'Annual Report of the Chinese Protectorate, for the year 1894', in Straits Settlements Annual Departmental Reports 1894, p. 349. 
sometimes voiced their objections to some legislation of which they disapproved, and attempted to assert their influence for change. ${ }^{55}$

The members of the upper 'Shih' class possessed comparable prestige and power to that of the merchants in the Chinese communities. Although they did not possess wealth, they were accorded high social status because of their jobs. Being junior officials and clerks of foreign firms, they commanded certain influence with foreigners. Their influence hinged upon their command of the English language. The ability to speak English meant opportunities for communication and contacts with foreigners on whom they could exert influence. This placed them in the key position between the Chinese communities and the British Colonial government. Their influence and status were recognized by the British authorities through their appointment as Jurors in the courts of the Straits Settlements. ${ }^{56}$

Junior officials as a group were more respected than clerks of foreign firms. They were seen as petty mandarins comparable to Yamen clerks and runners in rural China. ${ }^{57}$ As most of the Chinese immigrants had experienced the authority and power of the petty mandarins in China, they tended to regard the junior officials in the Colonial establishment with the same respect and fear. Among these officials, those who worked in the Chinese Protectorates and the Department of Police as clerks, interpreters and detectives, enjoyed even higher status and prestige than officials of other Departments.

The Chinese Protectorate, which was founded in $1877,{ }^{58}$ assumed

${ }^{55}$ For instance, the Penang Chinese Advisory Board in 1894 expressed its strong disapproval of the Women and Girls' Protection Ordinance Amendment, and insisted upon the necessity for a Reformatory. Ibid.

${ }^{56}$ Since 1874 , the Penang government had appointed some respectable Chinese as Jurors of the local court, many of them were clerks of foreign firms, on the Penang Juror list for the year I 882, Cheah Hay Seang was a cashier, Charter Bank; Lee Ah Seng, clerk of the Chartered Bank; Goh Quan Leam, clerk to A. M. Watson; Hoh Tek Cheong, clerk S. Kustermann \& Co., Hoh Tek Keng, clerk, Brown \& Co.; Koh Ah Fat, clerk, Brown \& Co.; Neo Choo chye, cashier, Mercantile Bank; Pan Ah Fat, clerk, Chartered Bank; Soh Teng Gan, clerk, Mercantile Bank, and others. See 'List of Penang Jurors for 1882', in Straits Settlements Legislative Council Proceedings 188I, appendix no. 35. In $188_{1}$, eleven Chinese were appointed Jurors by the Malacca government for the year 1882 , three of them belonged to the upper 'Shih' group. They were Chua Cheng Wee, clerk, Chua Kim Swee, auctioneer and Kho Choon Seng, Shroff of the Treasury Department. See 'List of Malacca Jurors for 1882 ', in ibid., appendix no. 36 .

${ }^{57}$ For the power and influence of the Yamen clerks and runners in Ch'ing China, see T'ung-tsu Chu, Local Government in China under the Ch'ing (Cambridge, Massachusetts, 1962), pp. 36-73.

58 For factors leading to the founding of the Chinese Protectorates in the Straits Settlements, see Eunice Thio, 'The Singapore Chinese Protectorate: Events and Conditions Leading to its Establishment, i 823-1877', in Journal of the South Seas Society (Singapore), vol. XVI, pts I and 2 (196o), pp. 40-8o. 
considerable power in the control of the Chinese communities in Singapore and Malaya. The Protectorate had its head office in Singapore, ${ }^{59}$ and branch offices in Penang and Malacca. Chinese Protectorates were also set up in the Protected Malay States with headquarters in each capital city of the states and branch offices in districts where the Chinese population was numerous. Apart from a few top officials, middle rank and junior officials of the Protectorates were Chinese. ${ }^{60}$ These officials seemed to have special authority over their Chinese compatriots. They were held in high respect because their authority had direct bearing on the Chinese population, their friendship was keenly cultivated by those Chinese who wanted special favour from them. Because of this, some of them tended to abuse their power and authority. In I 896, a Chinese clerk in the Chinese Protectorate, Telok Anson, Perak, was found guilty of collecting protection fees from local Chinese brothels. ${ }^{61}$ The same misuse of power was also found by a Chinese interpreter for the government in Raub, Pahang, in I $900 .{ }^{62}$

In contrast to the merchants and the educated elite, menial workers had a very low social standing in the overseas Chinese community. Although most immigrants started from the same basis, those who succeeded in amassing wealth climbed the social ladder to respectability, earning an image of being hard-working and smart; while those who failed were labelled lazy and unwise. ${ }^{63}$ There was little social sympathy for their poverty, which was deemed to be of their own making. ${ }^{64}$ As one writer put it, 'they did not know how to save money, and squandered their money on gambling and opium-smoking'. ${ }^{65}$ In the eyes of many people, menial workers had little social worthiness. Since they were struggling to make a livelihood, they were considered to be incapable of contributing a great deal to the community. For their lack of wealth and knowledge, they were deemed suitable only to be led and to be told what to do.

59 The office of the Singapore Chinese Protectorate was opened on I June 1877 . See 'Annual Report of the Protector of Chinese for the Year 1877 by W. A. Pickering dated 1 2th January 1878', in Straits Settlements Legislative Council Proceedings 1878 , appendix no. 6.

${ }^{60}$ In Kinta district, Perak, for instance, the Chinese Affairs office consisted of 5 people, the Acting Protector of Chinese, a Junior officer and 3 Chinese clerks. See The Perak Government Gazette I8gI, vol. 4, no. 26, p. 765 .

${ }^{61}$ See 'High Commissioner's Office Files (Federated Malay States)', I05/1896.

${ }^{62}$ See 'Selangor Secretariat Files' (British Resident's Office), 6746/1 goo.

${ }^{63}$ See Lat Pau, 23/1/19o8, p. I.

${ }^{64}$ See Siah U Chin, 'General Sketch' (see n. 9), p. 285.

${ }^{65}$ See Thien Jan Shin Pao, 15/5/1900, p. 2. 


\section{Class Relations}

What was the relationship between classes in the overseas Chinese community? This is a hard question to answer owing to the paucity of relevant materials. The relationships between plantation owners and plantation workers, between mining proprietors and mining workers, and between shopkeepers and shop assistants, formed the class relations in the overseas Chinese community. Like many other societies, class relations in the overseas Chinese community were basically interdependent and exploitative. The plantation owners, mining proprietors and shopkeepers wanted to maximize their profits. To achieve this aim, they mobilized all available resources including kinship and dialect ties, and the power of the secret societies, to ensure smooth industrial relations. Many shopkeepers took their kinsmen or relatives from China to work in their shops, ${ }^{66}$ as did the plantation owners and mining proprietors. Apart from kinsmen and relatives, preference for employment was given to people speaking the same dialect or belonging to the same secret society. ${ }^{67}$ Based on kinship and dialect ties and secret society brotherhood, the relationship between employers and employees was not seen in class terms, but as an extension of these ties. The employee was given the impression that his employment was not so much due to his merit, but to his possession of special relations with the employer, to whom he felt obliged. The basis of this relationship was not a formal contract, but a verbal promise of the employer regarding remuneration which undoubtedly placed the employee at his mercy. ${ }^{68}$

The class relation was seen not just from the perspective of personal ties, but also seen in the light of the traditional Confucian superiorsubordinate relationship. This relationship was mutual and paternalistic. The employer, who was also the kinsman, relative, or fellow district

${ }^{66}$ See Song Ong Siang, Chinese in Singapore, p. 96; see also Yen Ching-hwang, The Overseas Chinese and the IgI I Revolution: Wilh Special Reference to Singapore and Malaya (Kuala Lumpur, 1976), p. 4; for a similar situation in the Chinese community in the Philippines, see E. Wickburg, The Chinese in Philippine Life (New Haven and London, 1965), p. 172.

${ }^{67}$ Kapitan Yap Kwan Seng of Selangor, a Hakka, employed mostly Hakka coolies in his mines. In I 889, he had 7000 coolies on his pay roll. See 'Evidence given by Yip Kim Sheng (Yap Kwan Seng) to the commission on Ioth January 1891' (Evidence 174), in 'Report of the Commissioner Appointed to Enquire into the State of Labour in the Straits Settlements and the Protected Native States, 1891 ', C.O. 275/41, also in Straits Seillements Legislative Council Proceedings 1891, appendix.

${ }^{68}$ Sung Tzu-chiang, an employee of Wu Hsin-k'o, of Chop Teh Yuan in Singapore, appealed against $\mathrm{Wu}$ for his failure to pay verbally promised wages. This took place in 1888 or earlier. See 'Petition of Sung Tzu-chiang to the Protector of Chinese of the Straits Settlements', in G. T. Hare (ed.), Text Book of Documentary Chinese, pt 1, vol. I, pp. $13-14$. 
folk of the employee, assumed the position of superior, who had the welfare of his employee at heart, and who looked after the employee as much as possible. In return, the employee who obliged to owe him absolute loyalty, and worked to the best of his ability for him. Based on this mutual good faith, the employer would occasionally improve his employee's wages and working conditions, and he would take it as his moral duty to improve the quality of life of his employee, generally. When the employer-employee relationship was not based on kinship and dialect ties, it was easily strained. When a plantation owner or a mining proprietor recruited a number of coolies on contract, he saw that he was not morally obligated to do as much as for his kinsmen, relatives or fellow village folk. This made him more exorbitant in his demand for working value from employees. If his demand was not met, he ill-treated them. The ill-treatment took the forms of confinement, beating and starvation. In I 89o, the Acting Assistant Protector of Chinese in Penang, G. C. Wray, reported serious ill-treatment of Chinese coolies in a sugar plantation in Province Wellesley owned by Tan Kang Hok. A coolie was starved to death. ${ }^{69}$ The ill-treatment of Chinese coolies appeared to be widespread in the estates in Province Wellesley. ${ }^{70} \mathrm{On}$ the other hand, the absence of modern unionism placed the workers in a disadvantageous position vis-à-vis the employers. Firstly, the workers were not organized into groups, and had no confidence in themselves with regard to collective strength; secondly, they had no organizational mechanism through which to deal with the employers; thirdly, they had no organizations to coordinate their activities, and as a result, they possessed little bargaining power.

As pointed out by Michael Stenson, Chinese immigrant workers were characterized by poverty, ignorance, and a transitory nature; ${ }^{71}$ they were generally apathetic towards their common welfare. Added to these disadvantages was the attitude of the Colonial government which adopted a policy of minimum interference in the industrial relations of the Chinese, the labour laws adopted during the period under study

${ }^{69}$ See 'Chinese Labourers in Province Wellesley: a Report by G. C. Wray, Acting Assistant Protector of Chinese, to the Resident Councillor of Penang dated 2nd June, I89o' in Straits Setllements Legislative Council Proceedings 1890 , appendix no. 21.

${ }^{70}$ This was the evidence given by the Acting Senior District Officer of Province Wellesley, W. Egerton to the Labour Commission on 18 December 1890 . Egerton stated that ill-treatment of Chinese coolies took place in both Chinese and European estates, and some coolies were tied up and beaten. See 'Report of the Commissioners Appointed to enquire into the State of Labour in the Straits Settlements and the Protected Native States, I891', in C.O. 275/41.

${ }^{71}$ See Michael Stenson, Industrial Conflict in Malaya: Prelude to the Communist Revolt in 1948 (London, 1970), pp. 1-10. 
being mostly the codification of existing mining usage. ${ }^{72}$ As a result, some employers took advantage of the leniency of the laws and blatantly violated the contracts with their workers. For instance, sick workers were not sent to hospital as required by the contracts and this resulted in their death. In 1890 , it was reported that employers in Jelabu sent their sick workers to the government hospital on the verge of death because it was more convenient for them to die there. ${ }^{73}$ In 1893 , it was claimed that employers in Ulu Selangor worked their sick labourers to the point of death and threw them out of the mines to die by the roadside. ${ }^{74}$

However, there were two deterrents which checked the potential abuse of the system: the shortage of labour supply and the absconding of workers. The shortage of labourers for plantations and mines occurred in the Malay Peninsula and some parts of Southeast Asia at least up to the end of the nineteenth century. It meant that the employers had to offer good wages and good working conditions in order to attract workers to enter into contracts in the first place. When labour became more precious in the market, the employers had to take a friendly attitude towards their workers, and to comply with workers' demand for higher wages. ${ }^{75}$ The employers were also a ware that it would be difficult to acquire continuous labour supply if they developed a bad reputation in mal-treating workers.

Absconding was an effective weapon for workers to deter illtreatment by employers. Production would be disrupted because of the absconding of workers, and it would be too expensive for the employers to recover the absconded workers. But there were still reports of individual coolies running away and group desertion as a result of illtreatment by estate and mine owners. ${ }^{76}$

Absconding was not just a form of protest against employers' abuses, it

72 See Wong Lin Ken, The Malayan Tin Industry to 1914 (Tucson, i965), p. 74.

${ }^{73}$ See 'Annual Report for the State of Jelabu for $1890^{\circ}$ ', in British Parliamentary Papers: Accounts and Papers, C. 6576, I892, p. 79 .

${ }^{74}$ See 'The Administration Report of the State of Selangor for the year 1893', in British Parliamentary Papers: Accounts and Papers, C.7546, 1894, p. 27.

${ }^{75}$ In 1899 , the continued high price of tin created a great competition for labour in Selangor. High wages had been demanded by the coolies in tin mines. See 'Annual Report of the Chinese Secretariat of Selangor for 1899', in 'Selangor Secretariat Files' (British Resident's Office), 905/1900.

${ }^{76}$ See 'Chinese Labourers in Province Wellesley: a Report by G. C. Wray, Acting Assistant Protector of Chinese, to the Resident Councillor of Penang dated 2nd June, 1890', in Straits Settlements Legislative Council Proceedings 1890, appendix no. 2 I; 'Evidence given by W. Egerton, Acting Senior District Officer, Province Wellesley, to the Labour Commission on 18 th December, 1890', in 'Report of the Commissioners Appointed to Enquire into the State of Labour in the Straits Settlements and the Protected Native States, $1891^{\prime}$, C.O. $275 / 41$. 
was also a means of escaping from existing contracts. Some workers were induced by more pay or better working conditions offered by alternative employers, and they resorted to absconding. In I 888, serious absconding of Chinese coolies took place in Krian, Perak, when about $10 \%$ of the Chinese population ( 486 out of 4,697 ) absconded because of poaching of coolies by Chinese tin mining owners. ${ }^{77}$ Kho Bu Ann, a Chinese sugar planter who had 1,500 acres of sugar estate in Province Wellesley, complained that $50 \%$ of his Chinese coolies ran away. ${ }^{78}$ Towards the end of $\mathrm{I} 880 \mathrm{os}$, absconding from tin mines in Selangor became so serious that a Chinese Immigration Depot was set up to control the movements of mining labourers. ${ }^{79}$ The scheme was initiated by the local British Colonial government with the support of Chinese mining proprietors. The support of the Chinese Kapitan of Kuala Lumpur, Yeh Chih-ying and the leaders of the other dialect groups for the scheme indicates the serious effect of absconding on the Chinese community as a whole; ${ }^{80}$ as some of them were mining proprietors, their support for the scheme was an indication of deep concern for their economic interest.

Under this scheme, a brick building which could accommodate I, 200 men was constructed in Kuala Lumpur with funds raised in the Chinese community, and it was well supplied with water and other facilities. All newly-imported labourers (sinkheh) had to be registered at the depot and remained there at the expense of their brokers until employment was found for them. Employers who were in need of labour had to apply to the depot manager who communicated with the brokers. Agreements were made in duplicate and the particulars were registered at the depot. The agreement set out in detail the sum of money to be received in advance by the labourers, the term of service, the place of work, the scale of remuneration, the hours of work, and the nature of the food and

77 See The Perak Government Gazette 1899 , vol. 2, no. 6, pp. I90-1.

${ }^{78}$ See 'Evidence given by Kho Bu Ann to the Labour Commission on $27^{\text {th }}$ November, I 89o', in 'Report of the Commissioners Appointed to Enquire into the State of Labour in the Straits Settlements and the Protected Native States, 189 I', C.O. 275/ 4 I.

${ }^{79}$ See 'The Administration Report of the State of Selangor for the year 1890', in British Parliamentary Papers: Accounts and Papers, C. 6576 , pp. 39-40.

${ }^{80}$ According to a report, the British Colonial officer took the initiative to organize a meeting in September 1888 to discuss the question of absconding. Those invited were the Chinese Kapitan Yeh Chih-ying, prominent Chinese leaders Chao I-yung, Yeap Kwan Seng and Yeh Li-wang; the leader of Teochew group, K'o Ch'un-po; the leaders of Hokkien groups, Chao Shih-chu, Ch'iu Lien-ch'i, Ch'en Hsiang-p'u and Ch'en Chinlan; the leader of Ta P'u Hakka group, Chang Kao-ying and the leader of Chia Ying Hakka group, Li Ch'i-jen. The meeting resolved to raise money among Chinese merchants, and a fund-raising committee was formed. See Lat Pau, 10/10/1888, p. I. 
clothing to be provided. ${ }^{81}$ On the expiration of a sinkheh's term of service, he was to obtain a certificate stating that his agreement had been fulfilled. On presenting it to the depot he was registered as a 'laukheh' (old hand). He was then free to take service where he chose as long as he held the certificate of fulfilment of the contract. At the same time, employers who engaged labourers not provided with such a certificate were liable to a fine of $\mathbf{S} \$ 200 .{ }^{82}$ To prevent sinkhehs absconding to other states, a pass was to be obtained from the Chinese Kapitan before any coolie was allowed to leave Selangor. ${ }^{83}$

The key to the control of the movements of labourers was the certificate of fulfilment of the contract and the interstate pass. Obviously the absconded workers were unable to obtain the certificate and hence had difficulty in finding alternative employment. The inability to obtain a pass meant they had little chance of running away to other states. The heavy fine imposed on the employers who engaged unregistered labourers effectively prevented the poaching of labourers from other employers. The scheme was managed by a committee of Chinese headed by the Chinese Kapitan. ${ }^{84}$ The operation of the scheme was reported to have achieved great success, in solving the problem of absconding. ${ }^{85}$ In retrospect, the scheme also closed a channel of social protest by workers against employers' ill-treatment, and seemed to have placed workers in a disadvantageous position vis-à-vis the employers. Although the scheme appears to be fair to both workers and employers by stating conditions and obligations of both sides in the agreements, it worked in favour of the latter. There was no way to ensure the employers fulfilling the contracts, and they could manipulate their power of issuing the certificate. They could use the certificate as a threat in order to extract more services from workers than stated in the contracts. Whether the operation of this scheme can be interpreted as a conspiracy between Chinese mining capitalists and the British Colonial government in oppressing the workers is a matter of controversy. Perhaps the government was unconsciously in favour of the employers because they

${ }^{81}$ See 'The Administration Report of the State of Selangor for the year 1890 ', in British Parliamentary Papers: Accounts and Papers, C. 6576 , p. 40.

82 lbid.

${ }^{83}$ In giving evidence to the Labour Commission on 10 January 1891 , the Chinese Kapitan of Selangor, Yap Kwan Seng (Yip Kim Sheng), stated that no Chinese coolie could leave the state unless provided with a pass issued by him. See 'Report of the Commissioners Appointed to Enquire into the State of Labour in the Straits Settlements and the Protected Native States, 189 ', in C.O. 275/41.

${ }^{84}$ See 'The Administration Report of the State of Selangor for the Year $1890^{\prime}$, in British Parliamentary Papers: Accounts and Papers, C. 6576 , p. 40. 
happened to be wealthy capitalists who had frequent contacts with government officers; ${ }^{86}$ or perhaps they were an organized group and were able to articulate and press for their demands, ${ }^{87}$ while, by comparison, the workers were generally illiterate, ignorant and unorganized, and had no way to pass their opinions to the government.

\section{Social Mobility}

Chinese society in Singapore and Malaya during the period under study was full of stories of 'rags to riches', men arrived from China as poor 'sinkhehs' who rose to become wealthy capitalists within one generation. Song Ong Siang's One Hundred Years' History of the Chinese in Singapore (London, 1923) and Arnold Wright's edited work Twentieth Century Impressions of British Malaya (London, 1908) contain many biographies of the wealthy Chinese in the region, and provide rich materials for such study. Men like Tan Che Sang and Seah Eu Chin (Siah U Chin) of Singapore, Chang Pi-shih (Thio Tiauw Siat) of Penang, Kapitan Yap Ah Loy of Kuala Lumpur and Towkay Yau Tat Shin of Ipoh belonged to this category. The life stories of these capitalists provide us with insights into the social mobility in the overseas Chinese community.

Tan Che Sang was born in $\mathrm{I}_{7} 63$ in Chang Chou prefecture, ${ }^{88}$ Fukien province, in a poor family. He left China at the age of 15 for South Seas (Southeast Asia) in quest of economic advancement. His first destination was Rhio, a Dutch port where he worked for few years. When Penang was founded as a free port in $\mathrm{I} 786$, he was attracted to the new settlement and remained there for ten years. He then proceeded to Malacca, and finally settled in Singapore. ${ }^{89}$ He was known to be one of the wealthiest Chinese in early Singapore, kept his money in iron chests,

${ }^{86}$ See John Butcher, The British in Malaya $1880-194 I$ : The Social History of a European Community in Colonial Southeast Asia (Kuala Lumpur, 1979), pp. 67-8.

${ }^{87}$ See Wong Lin Ken, The Malayan Tin Industry to 1914, p. 73.

88 According to Song Ong Siang, Tan Che Sang was a Cantonese born in Canton in 1 763. But Professor Hsu Yun-ts'iao claims that 'Tan Che Sang's real name was Tan Sang (Ch'en Sung), the word 'Che' was the transliteration of a Southern Fukien term 'Shu' (uncle) which was a title of respect given to an older person, and Tan Sang was a Southern Fukienese. Strong evidence given by Professor Hsu to his claim is that Tan Che Sang was buried in the Heng Shan Cemetery which was controlled by the Chang Chou and Ch'uan Chou people of southern Fukien. I think Professor Hsu's claim can be supported further by the fact that 'Tan' is the romanization of the surname 'Ch'en' of Southern Fukienese or Teochews. If Tan Che Sang was a Cantonese, his surname should normally be romanized as 'Chan' rather than 'Tan'. See Hsu Yun-ts'iao, Ma-lai-ya ts'ung-t'an (Anecdotal History of Malaya) (Singapore, I961) pp. 27-8; Song Ong Siang, Chinese in Singapore, p. 13. 89 Song Ong Siang, ibid. 
and often slept among them. ${ }^{90} \mathrm{He}$ wielded enormous influence and power over his compatriots in the island. ${ }^{91}$

Seah Eu Chin was born in Swatow, Kwangtung Province, in I805. His father was a yamen secretary, which enabled Seah to receive a Chinese classical education. He came to Singapore in I 823, and worked on board a Chinese junk. He was then attached to several vessels as a clerk. Engaged in bartering with the Malays for five years, he learned much about their customs, habits and needs. This valuable experience laid the foundation for his future success in business. He established an agency house in Circular Road in Singapore supplying trading junks with provisions and receiving from them on commission the produce they had collected. ${ }^{92}$ Having been successful in commission business, he invested his money in real estate. As Singapore was booming, his investment in landed property reaped handsome profits. His business enterprises grew and extended to agricultural plantations; he was the first Chinese owner of large gambier and pepper plantations in Singapore. He was also a general trader dealing in Chinese tea and European cotton piece goods, and had extensive contacts with the European community so that he was made a member of the Singapore Chamber of Commerce in 1840 , probably the first Chinese to be admitted into that organization. ${ }^{93}$ He became the leader of the Singapore Teochew community around 1830 when he was elected as the president (tsungli) of the Ngee Ann Kun, a dialect organization representing all Teochews in the island. ${ }^{94}$ His leadership status among the Teochews was shown by his representation of the Teochew community in dealing with the government. ${ }^{95} \mathrm{He}$ was then recognized

90 See C. B. Buckely, An Anecdotal History of Old Times in Singapore (Kuala Lumpur, 1965, reprint), p. 2 I 6; Hsu Yun-ts'iao, Ma-lai-ya ts'ung-t'an, p. 28.

${ }^{91}$ It was reported in Singapore Chronicle that Che Sang was asked to settle a dispute involving three Chinese men who struck down a poor woman into the gutter. With the permission of the government, he sentenced the three men to receive a dozen lashes each, inflicted on them publicly with a ratan. See Singapore Chronicle, 3/3/1831.

92 Song Ong Siang, Chinese in Singapore, pp. 19-20; 'She Yu-chin hsien-sheng' (Mr Seah Eu Chin), in P'an Hsing-nung (ed.), Ma-lai-ya Ch'ao-ch'iao t'ung-chien (the Teochews in Malaya) (Singapore, 1950), pp. 78-80.

${ }^{93}$ Song Ong Siang, ibid.; P'an Hsing-nung (ed.), ibid.

${ }^{94}$ See 'letter from Yang Chan-wen to the Directors of the Singapore Teo Chew Poit Ip Huay Kuan and the Ngee Ann Kongsi dated 28 th October 1965', in P'an Hsing-nung (ed.), Souvenir Magazine of 40 th Anniversary of the Singapore Teo Chew (Poit Ip) Huay Kuan and the Commemoration of the 15oth Anniversary of the Founding of Singapore (Singapore, 1969), p. 164 .

95 In May 1873 , leaders of the three powerful dialect groups in Singapore petitioned the government to suppress the kidnapping of new immigrants in Singapore. Tan Kim Cheng and Cheang Hong Lim represented the Hokkien group, Seah Eu Chin and Tan 
by the British Colonial government in Singapore as an important leader of the whole Chinese community, ${ }^{96}$ and his assistance was sought to restore law and order in Singapore in $1849,{ }^{97}$ and in 1854 following the great Hokkien and Teochew riots. ${ }^{98}$ At the time of his death in 1883 , his estate was estimated to be worth $\mathrm{S} \$ 1,359,000 .{ }^{99}$

Chang Pi-shih was born in Ta P'u district, Kwangtung province, in 1840. His father was a Hsiu-ts'ai (Budding talent), ${ }^{100}$ and Pi-shih had a chance to receive some traditional Chinese education at home. At the age of 17 (in $185^{6}$ ), he left home for the Dutch East Indies to seek his fortune. He arrived in Batavia and worked as an assistant in a shop owned by his maternal uncle. He was young, intelligent and hardworking. His pleasant demeanour and good behaviour earned him the love of the daughter of the proprietor of a neighbouring rice shop which resulted in their marriage. With the help of his father-in-law, in 1865 he founded a company named $\mathrm{Yu}$ Ho engaged in the development of coconut and rice plantations. ${ }^{101} \mathrm{He}$ established a good relationship with the Dutch Colonial government in Java and acquired from it the monopoly of opium and liquor sale. Within a few years, he emerged to become a prominent merchant in Java. ${ }^{102}$ In 1877 , he extended his business enterprises to North Sumatra. He owned large plantations of coconut, rubber, pepper, coffee and tea, and founded a bank and a shipping line. His steamers running between Penang and Acheh competed successfully with European ships. ${ }^{103}$

In the I88os, Chang Pi-shih extended his business empire to the Malay Peninsula. Using Penang as his base in the Peninsula, his

Seng Poh represented the Teochew community, and Hoo Ah Kay (listed as Hoo Ah Kee) represented the Cantonese group. See 'Petition from Chinese merchants relative to the Treatment of Chinese Immigrants dated 3oth May, 1873', in Straits Settlements Legislative Council Proceedings 1873, appendix no. 33.

${ }_{96}$ Song Ong Siang, Chinese in Singapore, pp. 19-20; Yong Ching Fatt, 'Chinese Leadership in Nineteenth Century Singapore', in Journal of the Island Society (Singapore), vol. I (1967), pp. 4-6.

${ }^{97}$ See The Singapore Free Press, $1 / 3 / 1849$.

${ }^{98}$ See Wilfred Blythe, The Impact of Chinese Secret Societies in Malaya: A Historical Study (London, 1969), p. 156.

${ }^{99}$ See Straits Settlements Law Reports, vol. 4 (1897), p. 28.

${ }^{100} \mathrm{Hsiu}$-ts'ai was the title given to those who had passed the first stage of the imperial examination in Ch'ing China.

${ }^{101}$ See K'uang Kuo-hsiang, 'Chang Pi-shih ch'i-jen' (The man Chang Pi-shih), in K'uang Kuo-hsiang, Pin-ch'eng san-chi (Anecdotal History of Penang) (Hong Kong, 1958 , pp. $98-9$.

${ }_{102}$ See 'Chang Pi-shih', in H. L. Boorman and R. C. Howard (eds), Biographical Dictionary of Republican China (New York, I 967), p. go.

${ }^{103}$ See Anthony Reid, The Contest for North Sumatra: Acheh, the Netherlands and Britain 1858-1898 (Kuala Lumpur, 1969), pp. 194, 260. 
company, named Tung Hsing, was involved in mining in Bentong and Klang, and in the construction of commercial towns. ${ }^{104}$ By the end of the nineteenth century, Chang was widely recognized as one of the wealthiest Chinese capitalists in Southeast Asia. With his wealth, reputation and his special connection with Huang Tsun-hsien, ${ }^{105}$ the Chinese Consul-General for the Straits Settlements, Chang was appointed as the Chinese Vice-Consul in Penang in $1893,{ }^{106}$ In I 895 he was appointed Acting Consul-General of the Straits Settlements. ${ }^{107} \mathrm{In}$ early 1903 , he donated a sum of 200,000 taels to the Bureau of Railway and Mining (Lu K'uang Chi) for setting up its new technical school. As a result, he was recommended by the Governor-General of Chihli, Wang Wen-shao, to the court for a special award. ${ }^{108} \mathrm{He}$ was given an imperial audience by the Empress-Dowager Tz'u-hsi, and was made an Expectant of Third Rank Director of Court of Sacrificial Worship (Sanp'in ching-t'ang hou-pu), ${ }^{109}$ and was conferred an official title of Vice President of a Board (Shih-lang hsien) pending an appointment after the establishment of the proposed Ministry of Commerce. ${ }^{110}$ His official career reached its peak in $1904-05$ when he was appointed Imperial Commissioner to Inspect Commercial Affairs (K'ao-ch'a shang-wu tach'en) and concurrently the Imperial Commissioner in Charge of Agriculture, Industry, Railway Mining Operations of the Kwangtung and Fukien Provinces. ${ }^{11}$ Chang was thus heavily involved in the development of the modern Chinese economy, including railway construction, mining, agricultural farming and manufacturing. ${ }^{112}$

${ }^{104}$ See Anonymous, 'Chang Pi-shih', in K'e Chia: P'i-li K'e-hsukung-hui k'ai-mu chi-nien t'e-k'an (Hakka: Souvenir Magazine of the Opening Celebration of the Hakka Association of Perak) (Penang, 1951), p. 506.

105 See Hsueh Fu-ch'eng, Ch'u-shih kung-tu (Correspondence of My Diplomatic Mission), vol. 2, pp. 25a-25b. $\quad{ }^{106} \mathrm{lbid} . \quad{ }^{107}$ See Sing po, 1/11/1895, p. 8.

${ }^{108}$ See 'Memorial of Governor-General Wang Wen-shao and others to the Court dated 26 th day of 2nd moon of 29th year of Kwang-hsu (24th March, 1903)', in $\mathrm{ru}_{u \text {-chi }}$ hui-isun (Collected Records of Imperial Decrees and memorials) (Taipei, 1967, reprint) vol. $5^{1}$, pp. $1487-8$.

${ }^{109}$ Directors and Sub-Directors of the Court of Sacrificial Worship were generally designated as 'Ching-t'ang'. See H. S. Brunnert and V. V. Hagelstrom, Present Day Political Organization of China (Taipei, reprint).

${ }^{110}$ See Ta-ch'ing te-tsung ching-huang-ti shih-lu (Veritable Records of the Emperor Kuang-hsu of the Great Ch'ing Empire) (Ch'ang ch'un, 1935), vol. 5 I6, p. 5 b.

${ }_{111}$ Ibid., vol. 535, p. 6b; Cheng Kuan-ying, Chang Pi-shih hsien-sheng sheng-p'ing shihlueh (A Brief Biography of Mr Chang Pi-shih), p. I 4 .

112 See Michael R. Godley, 'Chang Pi-shih and Nanyang Chinese Involvement in South China's Railroads 1896-191 I', in Journal of Southeast Asian Studies, vol. 4, no. I (March 1973), pp. 16-30; see also Michael R. Godley, The Mandarin-Capitalists from Nanyang: Overseas Chinese Enterprise in the Modernization of China 1893-1911 (Cambridge U.P., Cambridge, I 981 ), pp. 149-72. 
Yap Ah Loy was a man of different cut. Born in Hui Yang district, Huichow prefecture of the Kwangtung province, on 14 March $1837,{ }^{113}$ he was an ethnic Hakka. His father was an impoverished tenant farmer. The severe agrarian problems in South China were aggravated by the opening of the treaty ports and the political chaos as a result of the rise of the Taiping movement. Like many other peasant families, Yap's family was diven by outside forces to the brink of bankruptcy. Ah Loy had to spend his childhood as a 'cow-boy' (mu niu-t'ung) and, at the age of I 3 and ${ }_{4} 4$, he became a farming hand trying to eke out a living. He had no chance to receive any education.

In I854 Ah Loy left China for Malaya. He arrived in Malacca, and was helped by his clansman, Yap Ket Si (Yeh Kuo-sze) who found him a job as a mining worker at Durian Tunggal. After four months, Ah Loy left Durian Tunggal for Kessang where he was taken in by another kinsman named Yap $\mathrm{Ng}$ (Yeh $\mathrm{Wu}$ ) as a shop assistant, and he stayed there for about a year. Probably because he was not used to the local hot climate or his performance as a shop assistant not impressive, Yap $\mathrm{Ng}$ decided to send Ah Loy back to China with a sum of money. But when the junk was anchored off the coast of Johore, Ah Loy was enticed to gamble and lost all his money. ${ }^{14}$ Fearing disgrace, he decided to go to Lukut to try his luck. Lukut at that time was a booming tin mining town, and $\mathrm{Ah}$ Loy seized the opportunity and started his business enterprises from there. He was taken in by a fellow Huichow Hakka miner in $185^{6}$ as a cook. After three years' hard work, he saved a reasonable sum of capital; at the same time, he also learned a lot about the management of a tin mine and the way of controlling workers. With the help of his clansman Yap Fook (Yeh Fook), he started his business of selling and buying pigs and tin ores. With the great demand for pork consumption among the local Chinese population, his business was very successful. $\mathrm{He}$ thus extended his business activities to a neighbouring town, Sungei Ujong, where a large number of Hakka Chinese congregated. ${ }^{115}$

The rise of Yap Ah Loy's power and fame was, however, due to his close relationship with a fellow Huichow Hakka named Liu Ngim Kong

${ }^{113}$ See S. M. Middlebrook, Yap Ah Loy, published as an independent copy of the Journal of the Malayan Branch of Royal Asiatic Society, vol. 24, pt 2 (July 195I), p. 12; Yap Ah Loy, 'Yeh Ah-lai cha-chi' (Miscellaneous Records of Yap Ah Loy by his Subordinates, trans. by Hsu Yun-ts'iao), in Nanyang Hsueh-pao (Journal of the South Seas Society) (Singapore, June 1957), vol. 13, pt 1, p. 70.

${ }^{114}$ See Wang Chih-yuan, Yeh Teh Lai Chuan (A Biography of Yap Ah Loy) (Kuala Lumpur, 1958), pp. 19-20.

115 Yap Ah Loy (trans. by Hsu Yun-ts'iao, see n. 113), pp. 22-5; Middlebrook, pp. $14^{-15}$. 
(Liu Jen-kuang), a Panglima of the Chinese Kapitan of Sungei Ujong, Sheng Ming-li. ${ }^{16}$ War clouds gathered in Sungei Ujong when Ah Loy arrived. Because of continuous disputes over tin mining, the Malay chiefs and Chinese tin miners were divided into two opposing groups engaged in feud and war. Ah Loy was recommended by Liu Ngim Kong to Kapitan Sheng, and was made Deputy Panglima. Although Ah Loy was defeated in a major conflict in 1860 during which Kapitan Sheng was captured and killed, he nevertheless impressed many Chinese with his ability. Later when law and order were restored in that town, he was recommended to be the Kapitan of Sungei Ujong in $186 \mathrm{I} .{ }^{117}$ At the end of 1862 , Ah Loy left Sungei Ujong for Kuala Lumpur, a new mining centre, at the invitation of his old friend Liu Ngim Kong, who was then the local Chinese Kapitan. Ah Loy became the manager of Liu's tin mines with a good salary; at the same time, he started his own tin mines and in 1865 founded a Chinese drug store named 'Teh Sheng'. ${ }^{118}$ With his ability and the trust of Liu Ngim Kong, he emerged to become a powerful figure in Kuala Lumpur, and in I 868 succeeded Liu to become the Chinese Kapitan of Kuala Lumpur. ${ }^{119}$

His succession to the position of the Chinese Kapitan of Kuala Lumpur was a turning point in Yap Ah Loy's career. For the first time, he demonstrated his administrative ability and political acumen. $\mathrm{He}$ ruled the Chinese community in Kuala Lumpur with an iron hand and effectively maintained law and order. Of course, he used his political power to benefit himself economically, and become one of the largest tin miners in Selangor. ${ }^{120}$ But he quickly became involved in the civil war

116 Kapitan Sheng Ming-li was deified after his death to become Hsien shih-yeh who has been popularly worshipped by the Chinese in Kuala Lumpur and Seremban areas. For a biography of Kapitan Sheng, see Chang Ching-wen, 'Hsien shih-yeh chia-pi-tan Sheng Ming-li kung shih-lueh' (A BriefHistory of Hsien shih-yeh Kapitan Sheng Mingli), in Yang Ku-t'ing (ed.), Chi-lung-po Hsien-ssu shih-yeh kung ch'ang-miao shih-lueh (A Concise History of the Founding of the Hsien-ssu shih-yeh Temple of Kuala Lumpur) (Kuala Lumpur, 1959), n.p.

117 See Wang Chih-yuan, Yeh Teh Lai Chuan, pp. 30-1.

118 Ibid., pp. 44-7.

119 See Middlebrook, Yap Ah Loy, pp. 26-36; Yap Ah Loy (trans. by Hsu Yun-ts'iao), p. 71. Official recognition of Yap Ah Loy as Kapitan China by the Sultan of Selangor took place in I 873. See a short biographical note of Yap Ah Loy in 'Annual Report on

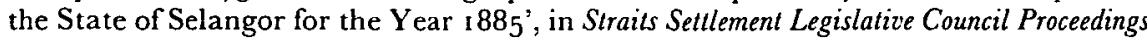
1886, appendix no. 22.

120 Yap Ah Loy (The Chinese Kapitan) was reported to be the main producer of tin in Selangor in 1879. See 'Report on the Revenue and Expenditure of the State of Selangor for the Year 1879 by the British Resident dated I 2 th May, 1880', in Straits Settlements Legislative Council Proceedings 1880 , appendix no. 15. 
in the state which lasted for several years. ${ }^{121}$ From March 1873 to 1880 , he was the de facto ruler of Kuala Lumpur, and proved to be an able administrator. ${ }^{122} \mathrm{He}$ was also a very successful capitalist. He was one of the richest men in Selangor owning numerous tin mines, plantations, factories, shops and land. 123

Towkay Yau Tat Shin (Yao Teh-sheng) was born in a peasant family in P'ing Yen district, Chia Ying prefecture of Kwangtung province. He received some traditional Chinese education but because of his poor background, he had to leave school at a very early age and worked as a transport coolie on the border between Kwangtung and Kiangsi. In quest of economic advancement, he left China for Malaya. He arrived in Sungei Ujong and worked in a tin mine as a coolie. With his ability, he was soon promoted to become a head coolie. But his ambition was to start his own mine and become a wealthy capitalist. ${ }^{124}$

He thus gave up his job and became a hawker which provided him with a better opportunity to save. When he was informed of a better mining opportunity in Perak, he quickly moved to Ipoh where he started a grocery shop named 'Teh Ho'. At the same time, he was making contacts to pave the way for his entry into mining enterprises. With his capital generated from his grocery shop and his business skills, he had a good start in tin mining. He then expanded his business, and joined with other rich miners like Cheng Keng Kwee and Loke Yew in buying up mining lands in Perak and Selangor. He was also involved in opium, liquor farming and building contracts. ${ }^{125} \mathrm{He}$ received a large contract from the Perak government to construct 300 shops in Ipoh, and thus became one of the richest Chinese capitalists in Malaya.

The life stories of the above wealthy capitalists reveal certain conditions which contributed to the rapid social mobility from the bottom to the top.

${ }^{121}$ For a good discussion on political and economic setting of this civil war, see Khoo Kay Kim, The Western Malay States 1850-1873: The Effects of Commercial Development on Malay Politics (Kuala Lumpur, 1975), pp. 53-1 43.

${ }^{122}$ Wang Chih-yuan, Yeh Teh Lai Chuan, pp. 69-171; Middlebrook, Yap Ah Loy, pp. 36-96; 'Hsueh-lan-ngo chia-pi-tan Yeh kung teh-lai fen-chan shih-lueh' (A Short History of Battles of Yeh Teh-lai, the Kapitan of Kuala Lumpur), in Yang K'u-ting (ed.), (see n. II6), n.p.

123 Wang Chih-yuan, Yeh Teh Lai Chuan, p. I 89.

${ }^{124}$ For a short biography of Yau Tat Shin, see 'Yao kung teh-sheng' (Mr Yau Tat Shin), in P'i-lichia-ying hui-kuan ch'i-shih chou-nien chi-nien, hsin-sha lo-ch'eng k'ai-mu t'e-k'an (Souvenir Magazine of 7 oth Anniversary Celebration of the Chia Ying Association of Perak and the Opening of its New Club House) (Ipoh, 1974), pp. 512-14.

125 In 1898 Yau appeared in the government records as tin miner and farmer (opium and liquor?). See 'High Commissioner's Office Files (Federated Malay States)', 454/ 1898 . 
a. Intelligence. This included components such as education, foresight, and administrative ability. The entrepôt trade in Penang and Singapore, and the rapid economic development in the Malay States provided excellent opportunity for immigrants to make fortunes. As the majority of the immigrants were illiterate, those with some education or foresight were able to exploit these opportunities. Seah Eu Chin and Chang Pi-shih's education proved to be valuable in their careers. While all of them seemed to have possessed foresight which guided them in their business enterprises. Once their business expanded, they needed administrative ability to manage their business empires. Yap Ah Loy and Chang $\mathrm{Pi}$-shih had demonstrated their extraordinary ability not only in their business managements, but also in political affairs.

b. Kinship and dialect ties. As the Chinese community in Singapore and Malaya was so rigidly segregated, kinship and dialect ties were most important in social connections. Those who had kinsmen, relatives and fellow villagers overseas stood a better chance of climbing the social ladder. The help that Chang Pi-shih and Yap Ah Loy received from their relatives and fellow villagers proved to be most valuable in their early successes.

c. The capacity to overcome certain disqualifications. There were many social 'evils' in the Chinese community, principally gambling, opium-smoking, drinking and prostitution. Involvement in these social 'evils' would reduce the ability of the immigrants to accumulate capital. Gambling was in particular an 'evil' that would destroy one's chance for upward social mobility. All the above wealthy capitalists seemed not to have the gambling habit, or indulged in opium-smoking. Yap Ah Loy who lost all his passage money in gambling had learned a lesson, and he does not seem to have gambled again.

This rapid mobility within one generation was one of the patterns of the upward social mobility in the Chinese society during the period under study. Another pattern was the rapid mobility within two generations. Under this pattern, the father was an immigrant who managed to accumulate some wealth to become a shopkeeper or owner of some enterprises. When his son who was local-born succeeded him, the business was expanded to become an empire, and the son became a wealthy capitalist. In fact, many of the life stories collected in Song Ong Siang's work are examples of this two-generation mobility. The stories of Teo Lee, Tan Kim Seng, Hoo Ah Kay, Wee Ah Hood and Cheang Hong Lim are some of them. ${ }^{126}$

${ }^{126}$ See Song Ong Siang, Chinese in Singapore, pp. $33,46,52$, 102, 168. 
The reasons for this two-generation rapid mobility are obvious. The immigrant who worked hard to save money had laid a solid foundation for his children. With this capital and business base, the children could achieve much rapid accumulation of wealth by expanding the business activities. They also acquired knowledge of how to do business from the father. On the other hand, as most second-generation Chinese were local-born, they received an English education which was crucial for contacts with the government and European capitalists; they were also more familiar with local conditions, and were therefore in a better position than the immigrants to accumulate wealth. This helps to explain why the Malacca-born Chinese were very successful in the early period of Singapore society. ${ }^{127}$

What we have discussed above are some of the patterns of upward social mobility, but these patterns by no means represent the norm. Those people who achieved rapid mobility within one and two generations were in the minority. Many Chinese immigrants did achieve some mobility in their lifetime. For a member of the artisan class to move up to become a merchant was relatively easy. For a carpenter, blacksmith, goldsmith, cook or tailor, he could start a shop to do business with a sum of money. Partnership was sometimes favoured because of the lack of a good banking system in the Chinese community. ${ }^{128}$ Thus an artisan became a proprietor-worker. On the one hand, he was working for wages; on the other, he worked not for an employer but for himself. If he put in more time, he would gain more return. A tailor was the best example in this category. He could start a small shop making clothes for coolies or shopkeepers, he would gain his handsome income as a proprietor-worker. Once he had saved more money, he could expand his shop or move to a larger shop, and would take in one or two apprentices. As business grew, he took in more apprentices, and would reduce his involvement in making clothes but remaining in a supervisory position. Eventually, he would become a merchant. This transformation of an artisan into a merchant could take years, depending on business itself. This process of transformation also took place among the apprentices. Those who had learned the skill and

${ }^{127}$ See C. M. Turnbull, The Straits Setllements 1826-67 (London, 1972), pp. 31-3.

128 This can be found in 'The Kwang Chao (Kwong Siew) Records' (unpublished, kept at the Kwang Chao Association (Kwong Siew Hui Kun), Kuala Lumpur). Many of these partnerships led to continuous disputes. Part of this 'The Kwang Chao Records' was published in Chi-lung-po Kwang Chao hui-kuan ch'i-shih chou-nien chi-nien ' 'e-k'an (Souvenir Magazine of the 7oth Anniversary Celebration of the Kwong Siew Association of Kuala Lumpur) (Kuala Lumpur, 1957), pp. 42-4. 
had saved some money would quit the master's shop and start a small shop of their own, and then expand to become merchants. ${ }^{129}$

For unskilled workers (coolies), upward social mobility was more difficult. These included the workers in plantations and mines, and rickisha pullers. As their labour could be easily replaced, they lost their bargaining power. Because of hard physical labour and frustration, they tended to indulge in gambling, opium-smoking and prostitutes. ${ }^{130}$ This further reduced their ability to save. In fact, only a small number of them succeeded in moving up the social ladder. There were several ways of achieving this upward mobility: to move up from a rickisha puller to rickisha owner; to become a hawker, peddler or small planter, and then a merchant. A small number of rickisha pullers managed to change their status to be rickisha owners. They were the coolies who were determined to climb the social ladder. They worked hard and resisted social evils. After having saved enough money, they bought their first rickisha and then purchased more and let out for hiring. ${ }^{131}$ Just as Chinese society today, the Chinese community in Singapore and Malaya during the period under study was rich in varieties of food which provided jobs as hawkers, meat, vegetable and fruit peddlers. Those coolies who had saved a small sum of money could change their jobs to become hawkers or peddlers. In the Malay states, some of the coolies could also become transient peddlers selling general goods and buying local produce in the Malay villages. ${ }^{132}$ The advantages of being hawkers, peddlers or transient peddlers were that their business required small capital, flexible working hours, and a better return for their labour. After succeeding in small business, they could then start a shop to become a merchant. To be a merchant was to be known and recognized. The

129 This process of transformation can still be found in country towns in Malaysia and other Chinese communities in Southeast Asia today.

130 See R. Little, 'On the Habitual Use of Opium in Singapore', in Journal of the Indian Archipelago and Eastern Asia, vol. 2 ( 1848 ), p. 20; Siah U Chin, 'General Sketch' (see n. 9), p. 295; in September 1846 , The Singapore Free Press reported that a large number of coolies from gambier and pepper plantations used to visit the town for the purpose of indulging in gambling, and spent their surplus cash in the different shops in town. But their visits ceased probably because a better opportunity for amusement had been provided in the jungle. See The Singapore Free Press, 1 7/9/1846.

${ }^{131}$ See 'Evidence given by W. E. Hooper, Registrar of Hackney Carriage, Jinrickishas, Singapore on Ioth August, 1907', in Straits Settlements and Federated Malay States Opium Commission rgo8, Proceedings, vol. 2 (Singapore, I 908), pp. 28-9.

${ }^{132}$ It appears that at the end of the 19 th and the beginning of the 2oth centuries, many Ying Chun immigrants (southern Hokkien dialect speakers) became transient peddlers between trading centres and distant villages; they also started small shops 'kedai' in the Malay kampongs for trading. See Tan Tek Soon, 'Chinese Local Trade', in The Siraits Chinese Magazine, vol. 6, no. 23 (Sept. I902), p. 90. 
status of merchant was acquired when someone started a shop dealing in goods and selling goods, and his activities were accepted by the local people as those of a merchant. When a hawker or a peddler struggled to become a merchant, he had to rent a shop and to give the shop a name. The shop's name must be registered with the government and accepted by the local community. Then the shop-owner would be recognized as a merchant. The acquisition of merchant status was important because a certain prestige and respect were accorded.

Alternatively, some coolies after serving their required terms changed to become small pioneer planters. They obtained a loan from shopkeepers in the city, cleared a piece of forest land and planted vegetables, plantains and indigo at first, and later crops such as pepper and gambier. ${ }^{133}$ The clearing and planting were hard and the return was slow. But if they endured to the time of production and hit the high market price, they would make a very lucrative return. With this success they changed their status to become a merchant or a planter-merchant.

\section{Conclusion}

Chinese immigrants did not bring with them a class system from China, but when they congregated overseas, their social grouping was influenced by their experience in China and the values prevalent in the village communities in Southeast China. The Confucian concept of hierarchical order left an indelible imprint on their minds, and had a profound impact on the creation of a class system overseas. In a community where mandarins, scholar-gentry or priests were absent, merchants ranked top of the social hierarchy, and wealth became the main channel of social mobility. In such a relatively fluid society, the rate of upward social mobility was higher than that in China. However, class distinction still existed, and class exploitation was hidden in a complex social relationship based on kinship and dialect affiliations. This quasi-Confucian superior-subordinate relationship was a useful social mechanism which the employers could use to smooth industrial relations, and to prevent the rise of modern unionism in overseas Chinese society.

${ }^{133}$ See J. D. Vaughan, The Manners and Customs of the Chinese of the Straits Setllements, p. 15 . 